J. Perinat. Med. $6(1978) 22$

\section{The effect of betamethasone therapy on the L/S-ratio in amniotic fluid}

\author{
K. Diedrich, M. Stefan, D. Krebs
}

Universitätsfrauenklinik Hamburg (Direktor: Prof. Dr. K. Thomsen)
The decision for premature termination of a pregnancy has to be weighed against the potential risk of the respiratory distress syndrome (RDS). This is particularly critical in pregnancies complicated by EPH gestosis, diabetes mellitus, rhincompatibility, placenta praevia, placental insufficiency, and in cases of premature labor. The difficulty of estimating fetal lung maturation seems to have been largely alleviated by introduction of the lecithin/sphingomyelin ratio (L/S ratio) measurement into perinatal medicine $[1,5$, $6,10]$. A further reduction in the risk of a premature born developing RDS is allegedly the administration prior to delivery of betamethasone to the mothers, a prophylactic regime first used by LIGGINS and HowIE $[8,9]$. These authors have reported a remarkably lower incidence of RDS in premature newborns whose mothers had received betamethasone. It is generally believed, that this effect is due to activation of alveolar enzymes inducing the formation of the surface active agents. By betamethasone, this process starts from cholin phosphate and diglycerides and finally results in an increased synthesis of lecithin $[3,4,11]$. We report here on the influence of betamethasone on amniotic fluid phospholipids. In this context consideration is also given to the effects of betamethasone administration on estriol excretion and on cortisol content in amniotic fluid.

\section{Material and Methods}

45 patients in the 27 th to 37 th week of pregnancy were treated with two intramuscular injections of

\section{Curriculum vitae}

KLAUS DIEDRICH was born in 1946 in Nordenham, Germany, studied in Hamburg and obtained his $M D$ there in 1971. Since 1974 he is working in the department of Obstet. and Gynecology of the University Hospital in Hamburg (Prof. Dr. K. THOMSEN). Main field of interest: Amniotic fluid and fetal development.

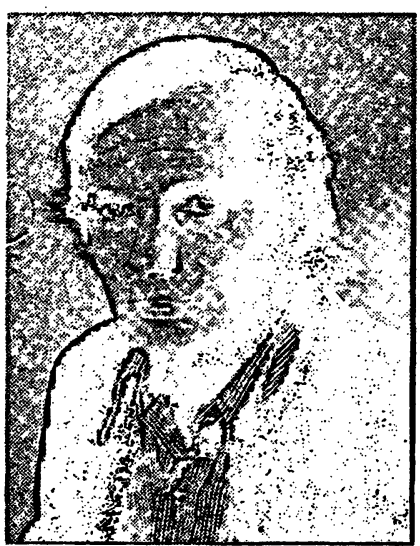

betamethasone (14 mg per dose) within 48 hours. An amniocentesis was carried out before and five to seven days after betamethasone application. In case of premature rupture of the amniotic sac a pessary was used for sample collection in order to prevent contamination of the amniotic fluid sample with vaginal contents.

$\mathrm{L} / \mathrm{S}$ ratios were determined using a modification of the method originally described by GLUCK [7]. In short, this method includes extraction of phospholipids from amniotic fluid by ether/methanol $(1: 1)$ (1 volume of amniotic fluid with 1 volume of ether/methanol) and after acetone precipitation separation of the phospholipids by thin layer chromatography. The stained areas of lecithin and sphingomyelin on the chromatogram were then quantitated by reflectance densitometry. According to GLUCK and other groups no RDS may be expected with an L/S-ratio exceeding 2.0. 
In addition, 24-hour-urine specimens were examined for estriol. Amniotic fluid cortisol concentrations were measured by radioimmunoassay using the method described by TUCHLINSKY [12].

\section{Results}

$\mathrm{L} / \mathrm{S}$ ratios were determined in amniotic fluid samples before and after betamethasone administration to 45 patients (Fig. 1). In samples from 9 patients before the 32 nd week of gestation only a slight increase in the $\mathrm{L} / \mathrm{S}$ ratio was observed after betamethasone administration (mean increase 0.28 ). In none of these patients was the critical limit of the $\mathrm{L} / \mathrm{S}$ ratio of 2.0 or more obtained.

In contrast, a substantial increase in the $L / S$ ratio (mean increase 1.5) could be found in 29 out of 37 pregnant women between the 32 nd to 37 th week of pregnancy.

In order to test whether the rise in the $\mathrm{L} / \mathrm{S}$ ratio could be attributed to betamethason administration a regression curve has been computed using individual $\mathrm{L} / \mathrm{S}$ ratio values from all measurements made during the various stages of pregnancy (Fig. 2). From the figure it becomes evident, that the slope of this regression curve increases during the course of pregnancy. Hence, the slope obtained from the $L / S$ ratio measurement in the two amniotic fluid samples of individual patients, could be directly compared with the expected increase of $\mathrm{L} / \mathrm{S}$ ratio in the respective week of gestation. It wasfound, that after betamethasone administration, the $L / S$ ratio of 34 out of 45 patients increased faster than would have been expected from the computed regression curve (Fig. 3). In 7 patients this increase was smaller than predicted. According to Dixon's and MooD's sign test this higher than expected increase in the $\mathrm{L} / \mathrm{S}$ ratio in these 34 patients can be attributed to betamethasone treatment. Furthermore, it becomes apparent from the figure, that this rise is much more pronounced after the 32nd week of pregnancy than at earlier stages of pregnancy.

Tab. I illustrates the frequency of RDS relative to the $\mathrm{L} / \mathrm{S}$ ratio determined up to 72 hours prior to delivery in a total of 108 patients. This group consists of 31 patients receiving betamethasone, and 77 patients receiving no treatment (control group).

Four betamethasone-treated patients delivered prior to the 32nd week of gestation were found to have a $\mathrm{L} / \mathrm{S}$ ratio of less than 2.0. The newborn of all four patients developped RDS despite preceding betamethasone therapy. Two of these RD syndromes were allegedly slight, while the two others were severe.

On the other hand, a significant higher incidence of RDS was observed in patients delivered between

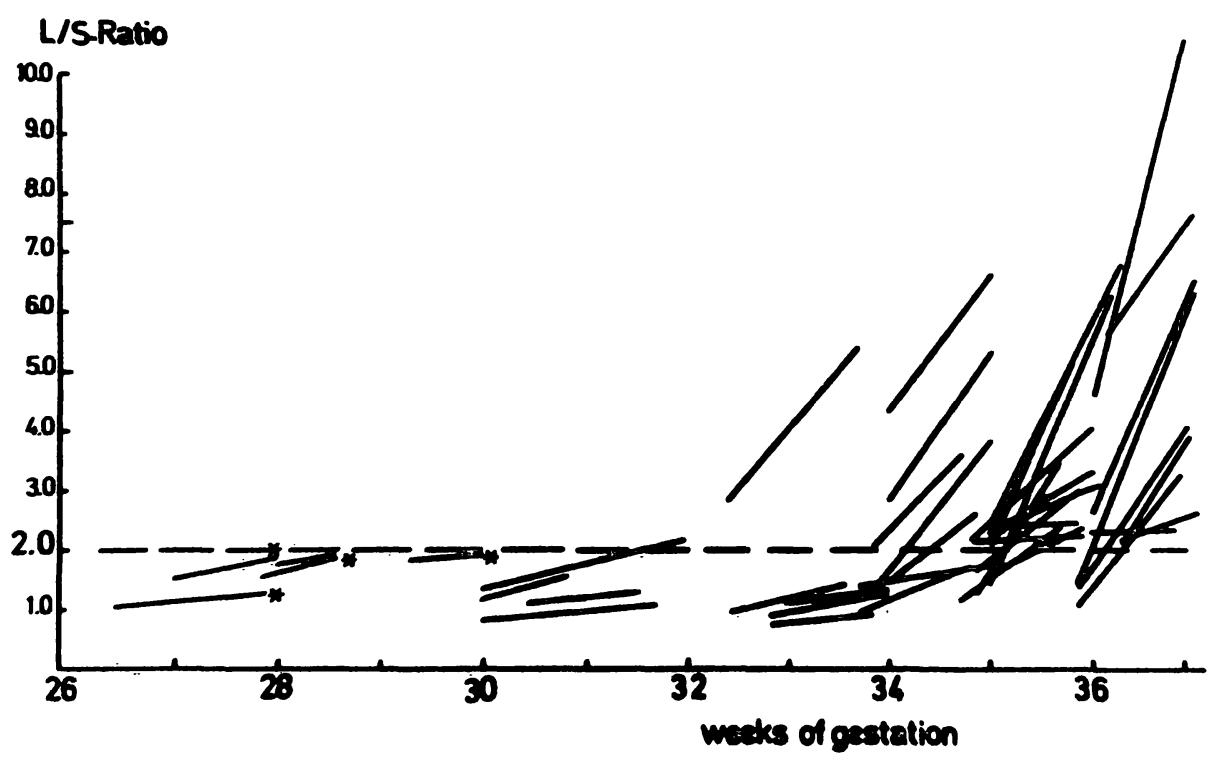

Fig. 1. The L/S-Ratio after Betamethasonetherapy $(n=45)$ 


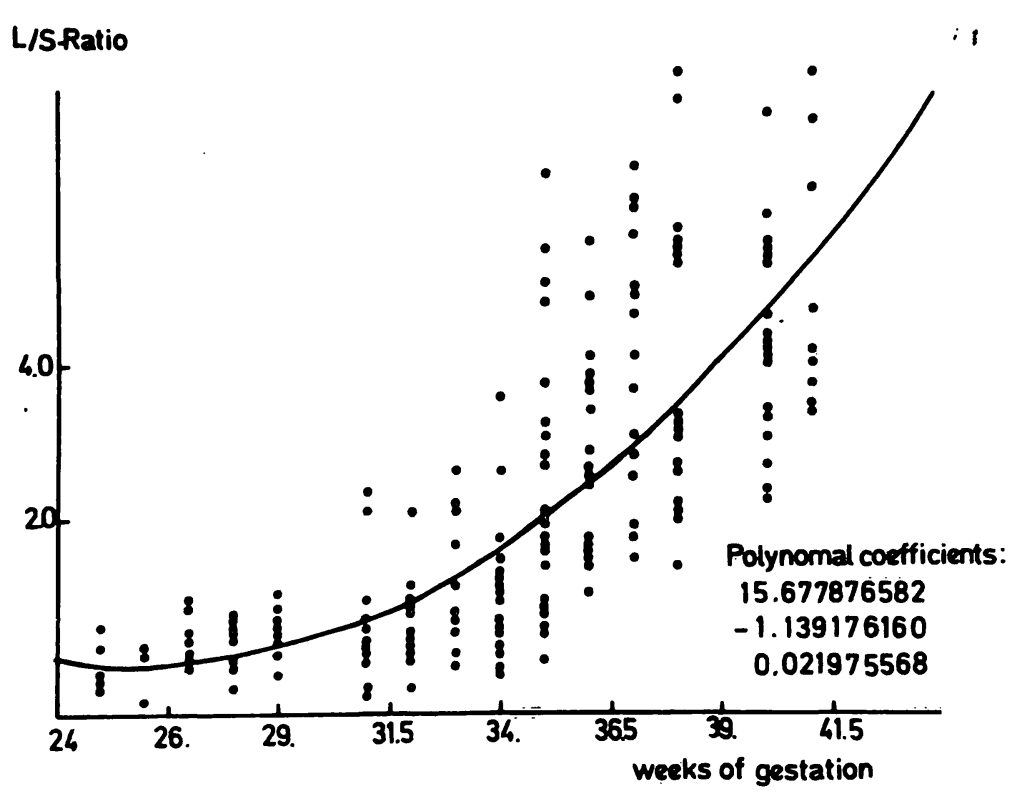

Fig. 2. Regression curve of the L/S-Ratio $(n=257)$

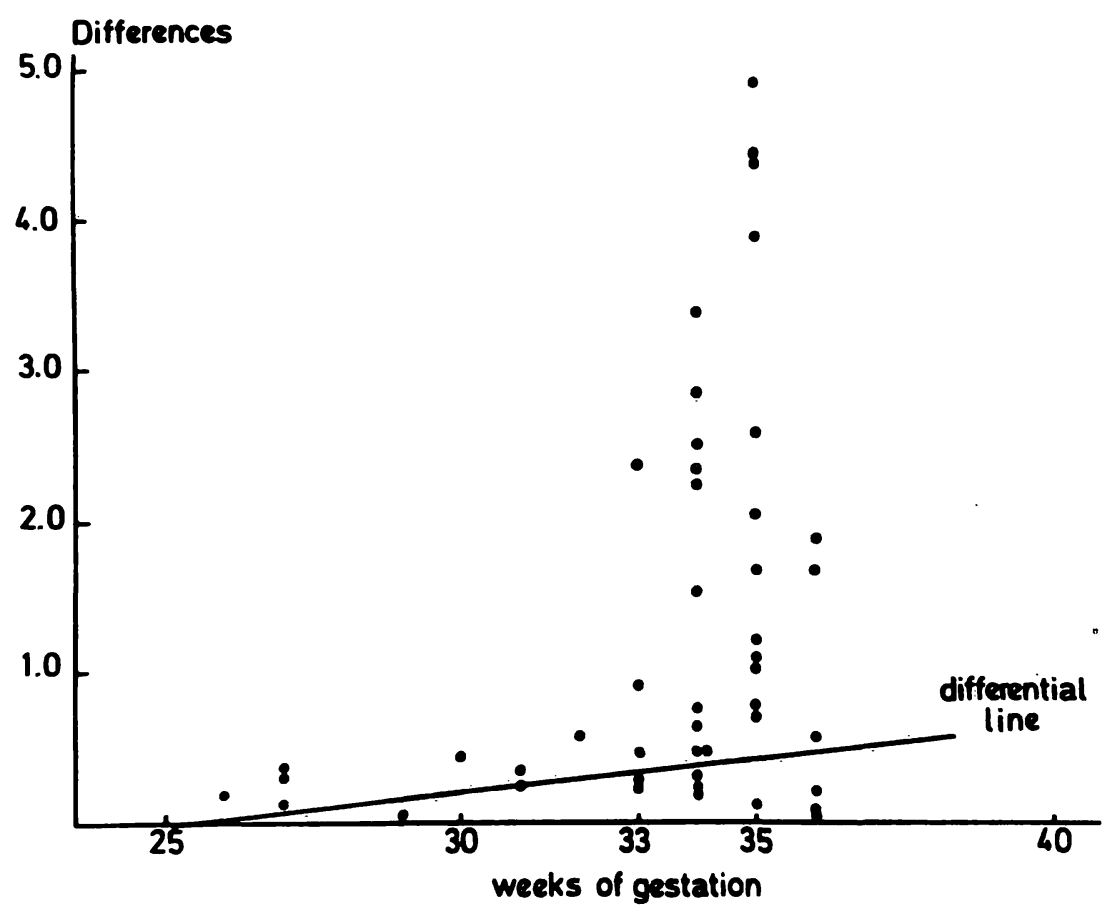

Fig. 3. L/S-Ratio: The differential line and the increase after Betamethasone administration $(n=45)$

Tab. I. The frequency of RDS in the Betamethasone group and the controll group.

\begin{tabular}{|c|c|c|c|c|c|c|c|c|c|c|c|c|c|c|}
\hline \multirow{2}{*}{$\begin{array}{l}\text { weeks of } \\
\text { gestation }\end{array}$} & \multirow[b]{2}{*}{$\mathrm{n}$} & \multirow[b]{2}{*}{ RDS } & . & Betan & Betamethasonegroup & group & average & \multirow[b]{2}{*}{$\mathrm{n}$} & \multirow[b]{2}{*}{ RDS } & \multirow[b]{2}{*}{$\%$} & \multicolumn{3}{|c|}{$\begin{array}{l}\text { controllgroup } \\
\text { degrees of severity }\end{array}$} & \multirow{2}{*}{$\begin{array}{c}\text { average } \\
\text { of the } \\
\text { L/S-Ratio }\end{array}$} \\
\hline & & & $\%$ & I & II & III & L/S-Ratio & & & & I & II & III & \\
\hline $\begin{array}{l}26 .-32 . \\
33 .-37 .\end{array}$ & $\begin{array}{r}5 \\
26\end{array}$ & $\begin{array}{l}4 \\
1\end{array}$ & $\begin{array}{l}80 \\
3.8\end{array}$ & $\begin{array}{l}2 \\
1\end{array}$ & & 2 & $\begin{array}{l}1.84 \\
4.1\end{array}$ & $\begin{array}{r}6 \\
71\end{array}$ & $\begin{array}{r}5 \\
14\end{array}$ & $\begin{array}{l}83 \\
19.7\end{array}$ & 7 & $\begin{array}{l}3 \\
5\end{array}$ & $\begin{array}{l}2 \\
2\end{array}$ & $\begin{array}{l}1.4 \\
2.65\end{array}$ \\
\hline
\end{tabular}


the 33 rd and 37 th week of gestation, if no betamethasone had been given (19.7\%) when compared to the betamethasone treated group (3.8\%). According to FISHER's exact probability test these data indicate a significant reduction of RDS incidence in the betamethasone treated group, which can be attributed to betamethasone. Such an interpretation is also supported by the significantly higher mean $\mathrm{L} / \mathrm{S}$ ratios in the betamethasone treated patients of this gestational stage (4.1 versus 2.65).

In 12 out of 26 patients exhibiting L/S ratios below the critical limits, corticoid treatment resulted in an increase of phospholipid concentration which made assumption of sufficient lung maturation a good probability. Estriol excretions in 24-hoururine specimens of patients receiving betamethasone, decreased by an average of $40 \%$ after the very day after initiation of therapy and did not rise to the original levels until two weeks had passed (Fig. 4). The effect of betamethasone on the amniotic fluid cortisol concentration was even more evident: The average cortisol concentration decreased by $60 \%$ five days after initiation of therapy, and rose to the original concentration within 2 weeks (Fig. 5).

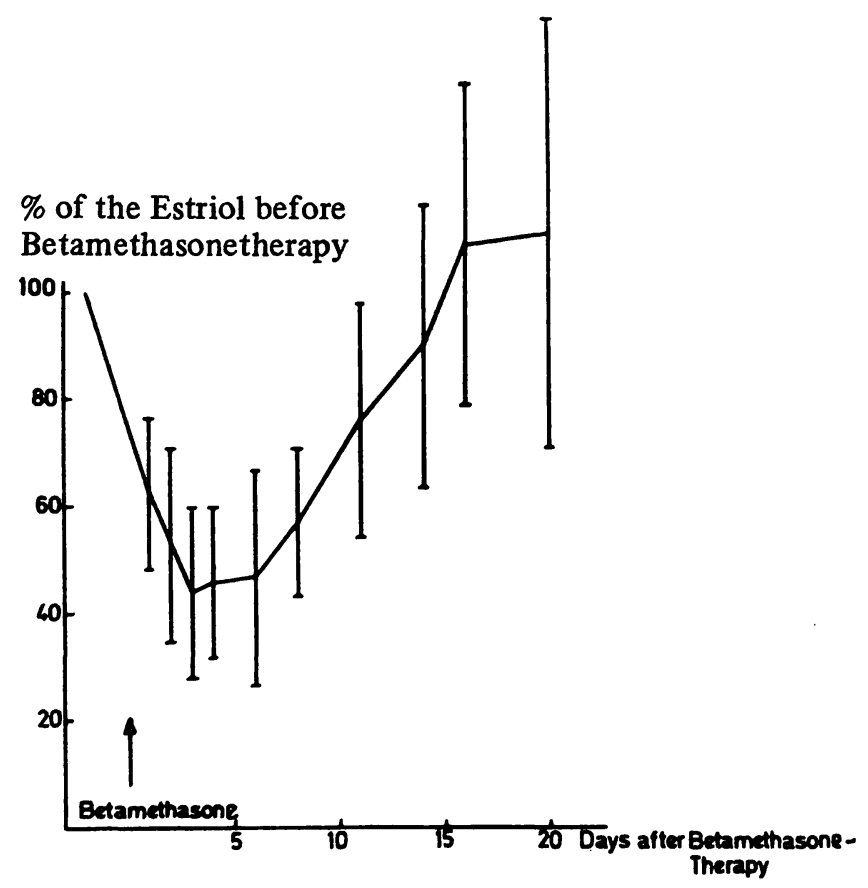

Fig. 4. Estriol after Betamethasonetherapy $(n=20)$

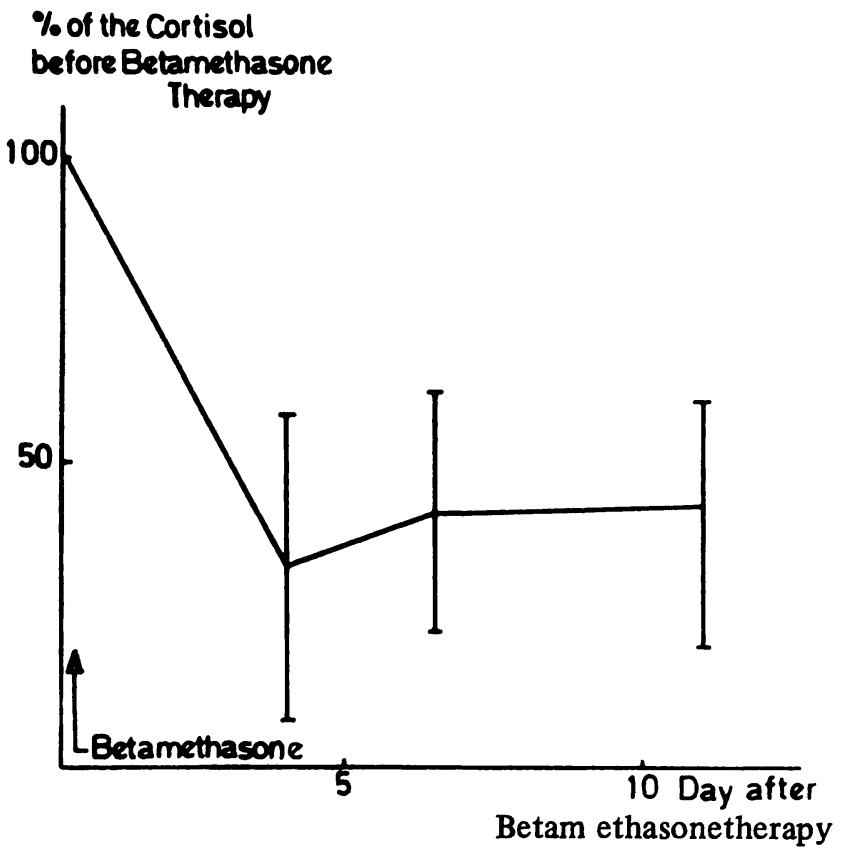

Fig. 5. Cortisol in the amniotic fluid after Betamethasonetherapy $(n=18)$ mean \pm SEM

\section{Discussion}

In nearly all patients after the $32 \mathrm{nd}$ week of gestation a significant increase in the amniotic fluid $\mathrm{L} / \mathrm{S}$ ratio has been observed after treatment with betamethasone. Although this period of gestation is accompanied by considerable increases in the $L / S$ ratio even without treatment, evidence for a positive effect of betamethasone treatment on the $\mathrm{L} / \mathrm{S}$ ratio could be presented by calculating the slope of increase of the L/S ratios. In 29 out of 37 betamethasone treated patients between the $32 \mathrm{nd}$ and 37 th week of pregnancy L/S ratios were such as to predict the development of RDS as very unlikely. Besides the positive effect which betamethasone has on the slope of increase of $\mathrm{L} / \mathrm{S}$ ratios, its beneficial effect can also be demonstrated on clinical grounds: As a comparison between the betamethasone-treated and a control group shows, there was a significantly higher incidence of RDS in the control group. In addition, RD syndromes in the control group tended to be clinical more severe.

On the other hand, no such increase of surfactant phospholipids could be found in patients treated with betamethasone before the 32 nd week of 
gestation. Moreover, the incidence of RDS was approximately the same in both, the treated and the control group of this gestational age. We interpret these findings as clinical evidence for a maturation process of the lecithin synthesizing enzyme system described by GLUCK [10] which does not significantly take place prior to the 32nd week. It is this system which is a prerequisite for the beneficial effects of betamethasone. Therefore, enzyme induction by corticoids essential for this enzymic pathway in alveolar cells, as has been described in JACOB's and MONOD's model is impossible prior to 32 nd -34 th week.

An expected finding in this work is the inhibitory effect of betamethasone on the fetal adrenal cortex, as evidenced by lowering of estriol excretion and amniotic fluid cortisol concentrations.

\section{Summary}

By. measuring the L/S-ratio in the amniotic fluid it becomes possible to make a perinatal estimate of the state of

Key words: Amniotic fluid, betamethasone, L/S-ratio, RDS. maturity of the fetal lungs. The determination of an inevitable premature termination of pregnancy is decisively influenced by the possible risk of respiratory distress syndrome (RDS). According to LIGGINS and others RDS in premature infants occur less frequently if before delivery mothers are treated with glucocorticoids. We determined the influence of betamethasone on the amount of phospholipids in the amniotic fluid before and after its administration to 45 mothers. Additionally the estriol excretion in the mothers' 24-hour-urine and the concentration of cortisol in the amniotic fluid were measured in order to evaluate the effect of betamethasone on the function of the fetal adrenal cortex.

It is demonstrated that in $\mathbf{3 4}$ out of 45 cases the evident increase of the L/S-ratio can be proved to be a direct effect of the betamethasone doses. The experiments thus show a significant increase of the L/S-ratio due to the treatment with betamethasone which is considerably stronger after the $32 \mathrm{nd}$ week of pregnancy as compared to the period previous to it. The percentage of RDS that occurred in the betamethasone group between the 33rd and the 37 th week is also significantly lower than that in the control group (3.8\% and $19.7 \%$ respectively). Before the 33rd week no significant difference could be found.

The distinct decrease in the excretion of estriol and in the concentration of cortisol show the inhibitory effect of betamethasone on the function of the fetal adrenal cortex.

\section{Zusammenfassung}

Der Einfluß des Betamethason auf die L/S-Ratio im Fruchtwasser.

Die fetale Lungenreife läßt sich durch die Messung der L/S-Ratio im Fruchtwasser weitgehend antepartal abschätzen. Die Festlegung einer notwendig werdenden Schwangerschaftsbeendigung wird entscheidend durch das mögliche Risiko eines Atemnotsyndroms beeinflußt. Nach LIGGINS u. a. tritt ein Atemnotsyndrom bei Frühgeborenen seltener auf, wenn die Mutter vor der Geburt mit Glukokorticoiden behandelt wurde. An 45 Frauen wurde der Phospholipidgehalt im Fruchtwasser vor und nach Betamethasongabe bestimmt.Zusätzlich wurde die Oestriolausscheidung im 24-Stunden-Urin der Mutter und die Cortisolkonzentration im Fruchtwasser gemessen, um die Wirkung des Betámethasons auf die Funktion der fetalen Nebennierenrinde zu beurteilen:
Es kann gezeigt werden, daß der Anstieg der L/S-Ratio als direkte Wirkung der Betamethasongabe in 34 von 45 Fällen nachweisbar ist. Dies ergibt einen signifikanten Anstieg der L/S-Ratio aufgrund der Betamethasonbehandlung. Diese Steigerung ist nach der 32. Schwangerschaftswoche erheblich stärker als vorher.

Auch die Zahl der Atemnotsyndrome ist zwischen der 33. und 37. Woche mit $3,8 \%$ in dem Betamethasonkollektiv im Vergleich zu dem Kontrollkollektiv mit 19,7 signifikant niedriger. Vor der 33. Woche zeigt sich kein erkennbarer Unterschied.

Im deutlichen Abfall der Oestriolausscheidung und der Cortisolkonzentration im Fruchtwasser zeigt sich die hemmende Wirkung des Betamethasons auf die fetale Nebennierenrindenfunktion.

Schlüsselwörter: Betamethason, Fruchtwasser, L/S-Ratio, RDS.

\section{Résumé}

Influence du bétaméthason sur le taux $L / S$ du liquide amniotique.

La mesure du taux $\mathrm{L} / \mathrm{S}$ du liquide amniotique autorise une estimation périnatale de l'état de maturité des poumons $\mathrm{du}$ foetus. Or, l'interruption prématurée de la grossesse dépend notamment du risqueéventuel d'asphyxie périnatale (Respiratory Distress Syndrom). Selon LIGGINS et al. cette forme d'asphyxie apparaît moins fréquemment chez les prématurés dont les mères avaient suivi un traitement de glucocorticoides. Nous avons appliqué la méthode mentionnée ci-dessus pour chercher à définir l'influence du bétaméthason sur les phospholipides du liquide amniotique avant et après son administration à 45 parturientes. De plus, nous avons mesuré le taux 
d'oestriol des urines de 24 heures ainsi que la concentration de cortisol dans le liquide amniotique afin de pouvoir évaluer les effets du bétaméthason sur le fonctionnement du cortex adrénal foetal.

A la suite de ces analyses, nous avons pu constater que dans 34 des 45 cas l'accroissement très net du taux L/S résulte directement de l'administration de bétaméthason. Cette hausse significative du taux L/S consécutive au traitement de bétaméthason est beaucoup plus forte après la 32 ème semaine de grossesse. Le pourcentage d'asphyxie périnatale observé dans le groupe traité au bétaméthason entre la 33 ème et la 37 ème semaine de grossesse est aussi beaucoup plus bas que chez le groupe de contrôle (pourcentages respectifs de 3,8 et $19,7 \%$ ), tandis qu'aucune différence significative n'avait été relevée avant la 33 ème semaine.

La baisse très nette de l'élimination d'oestriol et de la concentration de cortisol dans le liquide amniotique prouve l'effet inhibiteur du bétaméthason sur le fonctionnement du cortex adrénal foetal.

Mots-clés: Asphyxie périnatale, bétaméthason, liquide amniotique, taux L/S.

\section{Bibliography}

[1] BHAGWANANI, S. G., D. FAHMY, A. C. TURNBULL: Prediction of neonatal respiratory distress by estimation of amniotic fluid lecithin. Lancet 1 (1972) 159

[2] FOLCH, C., LEES, M., H. SLOANE-STANLEY: A simple method for the isolation and purification of total lipids from animal tissues. J. Biol. Chem. 226 (1957) 497

[3] GIANNOPOULOS, G.: Glucocorticoid receptors in lung. I. Specific binding of glucocorticoids to cytoplasmatic components of rabbit fetal lung. J. Biol. Chem. 215 (1973) 3876

[4] GianNOPOUlOS, G., S. MULAY, S. SOlOMON: Glucocorticoid receptors in lung. II. Specific binding of glucocorticoids to nuclear components of rabbit fetal lung. J. Biol. Chem. 215 (1973) 5016

[5] GLUCK, L., M. V. KULOVICH, R. C. BORER, P. H. BRENNER, G. H. ANDERSON, W. N. SPELLACY: Diagnosis of respiratory distress syndrome by amniocentesis. Amer. J. Obstet. Gynec. 109 (1971) 440

[6] GLUCK, L., M. V. KULOVICH: Lecithin-sphingomyelin-ratios in amniotic fluid in normal and abnormal pregnancy. Amer. J. Obstet. Gynec. 115 (1973) 539
[7] GLUCK, L.: Procedure for the intrauterine assessment of pulmonary maturity by the phopholipids in amniotic fluid ("cookbook"), University of Californie: 1971

[8] LIGGINS, G. C., R. N. HOWIE: A controlled trial of antepartum glucocorticoid treatment for prevention of the respiratory distress syndrome in premature infants. Pediatrics 50 (1972) 515

[9] LIGGINS, G. C.: Premature delivery of foetal lambs infused with glucocorticoids. J. Endocr. 45 (1969) 515

[10] LORENZ, U., H. RUTTGERS, M. FROMME, F. KUBLI: Significance of amniotic fluid phospholipid determination for the prediction of neonatal respiratory distress syndrome. Z. Geburtsh. Perinat. 179 (1975) 101

[11] SMITH, B. T., J. S. TORDAY: Factors affecting lecithin synthesis by fetal lung cells in culture. Pediat. Res. 8 (1974) 848

[12] TULCHINSKY, D., FENGL, M.: Total cortisol in anmiotic fluid and fetal lung maturation. N. Engl. J. Med. 16 (1975) 133

Received February 24 th, 1977. Accepted October 25 th, 1977.

Dr. K. Diedrich

Univ.-Krankenhaus Eppendorf

Frauenklinik

Martinistraße 52

D-2000 Hamburg 20 